\title{
Is the commercialisation of human tissue and body material forbidden in the countries of the European Union?
}

\author{
Christian Lenk, Katharina Beier
}

Department for Medical Ethics and History of Medicine, University Medical Center Göttingen, Göttingen, Germany

\section{Correspondence to}

Dr Katharina Beier, Department for Medical Ethics and History of Medicine, University Medical Center Göttingen, Humboldtallee 36, Göttingen 37073, Germany; kbeier@gwdg.de

Received 6 January 2011 Revised 27 April 2011

Accepted 24 May 2011 Published Online First 22 June 2011

\begin{abstract}
The human body and its parts are widely perceived as matters beyond commercial usage. This belief is codified in several national and European documents. This socalled 'no-property rule' is held to be the default position across the countries of the European Union. However, a closer look at the most pertinent national and European documents, and also current practices in the field, reveals a gradual model of commercialisation of human tissue. In particular, we will argue that the ban on commercialisation of body material is not as strict as it may appear at first sight, leaving room for the commercial practice of tissue procurement and transfer. We argue for more transparent information for patients and tissue donors, an intensified ethical debate on commercialisation practices, and a critical review of current normative principles.
\end{abstract}

\section{INTRODUCTION}

In March 2010, the public Northern-German Broadcasting Network (Norddeutscher Rundfunk, NDR) featured a report on trade of tissue samples from cancer patients who were treated at the University Medical Centre Hamburg-Eppendorf (UKE). Without the consent and even knowledge of patients, tissue samples originating from the normal diagnostic work of the hospital's pathology department were being offered for worldwide sale via the US enterprise Tristar. The chief pathologist of the UKE also worked as a consultant for Tristar. The medical centre's board of management explained that it supports the work of researchers with industrial enterprises. Beyond the chief pathologist's involvement with Tristar, the board of managers even approved three further sideline jobs with other enterprises. On request from journalists, the UKE declared the transmission of tissue samples without the informed consent and knowledge of patients as legal according to the hospital law of the Federal Estate of Hamburg, provided that the samples are anonymised. This practice was strongly criticised in public because of an obvious lack of transparency in the hospital's handling of tissue samples. Many observers were astonished to hear that the selling and transfer of diagnostic tissue samples to other countries without the patient's knowledge and informed consent is legal according to German law. ${ }^{1}$

\section{WHAT DOES 'COMMERCIALISATION' MEAN IN THE CONTEXT OF HUMAN TISSUE?}

The ethical and legal challenge of commercialisation of human tissue and body material arises from the fact that the human body and its parts are usually perceived as matters beyond the logic of the market. We understand commercialisation in this text to be the introduction of professional and systematic trading of human tissue in the medical area (for therapeutic or non-therapeutic purposes) - that is, the transfer of property concerning body material in exchange for a financial reward. Entities perceived as being beyond the spheres of market, prices and commerce are stepwise commodified. Once achieved, this commodification enables the compatibility of goods with an economic logic of supply and demand. Commercialisation practices in this context need to be seen in comparison with another dominant model, namely the donation of human tissue and organs for therapy and research. In principle, for both practices, the decisive precondition is the accurate attribution of property to a specific sample that was removed from the human body. It is generally assumed that one can only sell or donate entities that one has ownership in. ${ }^{i}$ From a scientific perspective, it is a fascinating feature of the UK's legal system that it is not, at least fully, clear (not even for the source of the material herself) whether it is at all possible to have property in human material that was extracted from the body. Only recently, an English law court decided that the loss of body material can also be seen as material damage to somebody's property. ${ }^{2}$ In comparison, continental legal systems, such as, for example, the German one, usually presuppose that a person whose body material was removed is then the owner of this material.

On closer inspection, however, the options for commercialisation of human tissue are more nuanced than the division between common and continental conceptions of this issue suggests. Different levels of commercialisation occur according to different groups of possible property in body material, donor rights, and the commercial value of body material. In general, one can distinguish four levels as the main elements of a gradual model of tissue commercialisation. ${ }^{3}$

'This principle is at least applied to all kinds of tangible and intangible goods which are no 'res extra commercium'. Against this background the question arises whether parts that are extracted from the human body are also 'res extra commercium' in the full sense. However, all jurisdictions know ways of finally assigning ownership to someone in the course of the procession of human body material. Moreover, when a person, for example, donates blood, we assume at least that this person has the right to dispose of her blood and to decide about its further use (which can then, according to the 'bundle theory of property', be interpreted as one stick or particular right of the full bundle of property rights). 
1. A strong anti-commercialisation approach would deny that body material can be property at all. Therefore the strict and comprehensive application of the 'no-property principle' would at the same time exclude the commercialisation of body material, even independently of the tissue donor's will.

2. The constricted use of samples because of the donor's or patient's right to determine the further use of his or her sample. For example, when the donor excludes commercial use of the sample, it cannot have any commercial value. A defined purpose of the use of body material delimits the possibility of body material's commercialisation for further uses.

3. The definition of a more or less fixed price for human tissue by a government authority without further control rights of the donor. For example, prices for different body materials are fixed in Belgium according to a ministerial decree. ${ }^{4}$ The underlying rationale of this official price system is to cover the accruing costs for the processing of materials without providing an incentive for additional profits.

4. The full commercialisation of body material with creation of prices on the free market and (as in level three) without further control rights of the donor. Body material that is extracted from deceased persons and processed further into a medical product (eg, as a surrogate for defective bone substance) can, according to many jurisdictions, be traded like other medical products - that is, can be bought and sold at a market price.

Such a gradual model of commercialisation practices, ranging from the complete exclusion of body material from property rights to an exhaustive trade of human tissue with free market prices, is also compatible with the so-called 'bundle theory of property rights' - that is, that there are more or less comprehensive bundles of rights regarding somebody's property in an entity. ${ }^{5}$ The strength of the gradual commercialisation model is twofold. On the one hand, it helps us to understand and analyse different constellations and phenomena in the field of commodification and trade of human tissue. On the other hand, it shows that the ethical and legal discussion should rather focus on the different elements and stages of commercialisation than on the question of whether or not we should allow the commercialisation of body material.

\section{THE ‘NO-PROPERTY RULE’ AND ITS FOUNDATIONS IN EUROPEAN DOCUMENTS}

Analysis of the meaning of commercialisation reveals the importance of the concept of property. This finding will rarely surprise anyone who grew up in a modern completely materialistic and economised society. In our societies, 'property' is the decisive concept for controlling an entity. However, according to most jurisdictions, the human body constitutes a significant exclusion from this general rule, a fact that is also mirrored in a number of important normative national and international documents. This exclusion is most commonly known as the no-property rule.

For example, Art 21 of the European Convention on Human Rights and Biomedicine (Oviedo Convention, 1997) states that 'the human body and its parts shall not, as such, give rise to financial gain'. In addition, Art 22 forbids the storage and use of body material that was originally taken from the patient for another purpose without 'appropriate information and consent procedures'. Comparable instructions can be found in the Council of Europe's Recommendation Rec (2006) 4. ${ }^{6}$ Art 7 of the Recommendation similarly states that 'biological materials should not, as such, give rise to financial gain'. However, literally taken, this principle is obviously regularly disregarded in medical practice. For example, donated blood is bought and sold by private enterprises or non-profit organisations, which finance their own activities with the received gains from this economic activity. A closer look at the exact wording of the no-property principle in the named documents shows that the position articulated there is much weaker than a position completely rejecting the commodification of body material. The human body and its parts shall not give rise to financial gain'-but this wording is perfectly compatible with levels (1) to (3) of the described gradual model of tissue commercialisation: body material can be someone's property, it can be procured, exchanged and traded for wider purposes and one can demand compensation for the processing of body material as long as this does not represent a 'financial gain'.

In contrast with research using human tissue, which is not regulated in a binding document at the European level, there exists a European Directive concerning the therapeutic use of human tissue and cells, the EU Tissue Directive (2004/23/EC). ${ }^{7}$ Although the main purpose of this Directive is rather to ensure the safety of the therapeutic use of tissue and cells at a medical or technical level, it also contains an interesting paragraph about the normative principles that should guide the procurement of tissue and cells for therapeutic uses. The Directive's article (18) reads as follows:

'As a matter of principle, tissue and cell application programmes should be founded on the philosophy of voluntary and unpaid donation, anonymity of both donor and recipient, altruism of the donor, and solidarity between donor and recipient. Member States are urged to take steps to encourage a strong public and non-profit sector involvement in the provision of tissue and cell application services and the related research and development.'

This normative agenda is surely compatible with the noproperty rule and also shows general support for non-profit activities. However, in a stricter sense, the cited paragraph does not necessarily require an outright non-commercial processing and passing on of body material. In so far as it mentions the donation of body material from the side of the primary 'source' of the tissue, it is also premised that the donor in principle has a property right in his/her body material and can then transfer this property right to institutions that will process and use the material. In addition, when Member States are urged to 'encourage a strong public and non-profit sector involvement', it is-at least implicitly-assumed and accepted that there is equally a private and for-profit sector serving the same purposes.

One can conclude that there are a number of declarations of intent in high-profile European documents on medical practice and research on human tissue that demonstrate a clear normative tendency towards the avoidance of the full commercialisation of body material. However, a closer look reveals that the exact wording is always very reluctant and, with regard to the binding power of the respective paragraphs, leaves much space for commercial practices in the handling of human tissues and cells.

\section{THE SITUATION IN SELECTED EUROPEAN COUNTRIES}

The perusal of European documents-as a common featurereveals a generally critical opinion of commodification of the

iifor a more extensive discussion of national peculiarities in the handling of human tissue for research purposes, see Beier and Lenk. $^{8}$ 
human body. However, it is not clear what kind of influence European terms of reference have in individual cases and fields. In addition, different kinds of documents and guidelines will have different effects on the situation in different EU member states. European Directives (such as the EU Tissue Directive), for example, have to be transformed into national law after a specified time period. Conventions (such as the European Convention on Human Rights and Biomedicine) have to be ratified by the individual countries ${ }^{\mathrm{iii}}$ and will then develop an influence on national guidelines and law. Recommendations of the Council of Europe (eg, the Recommendation Rec(2006)4 of the Council of Europe's Committee of Ministers to Member States on Research on Biological Materials of Human Origin) can give orientation in a specific field, but have no binding power. Owing to this variety of normative documents and the number of Member States, in practice, different interpretations and pathways of regulation will occur. It is therefore important (and also inspiring) to take note of the situation in different Member States. It is a peculiarity of the field of human tissue and body material that, besides the common official normative framework (ie, the no-property rule), different approaches to tolerating the commodification of human tissue and body material can be observed in practice. In the following, we will provide a brief outline of the situation in Belgium, Germany, Spain and the UK.

\section{Belgium: officially fixed prices for body material}

In a way, the situation in Belgium is atypical in comparison with other countries, because it is the only European country where the EU Tissue Directive (for the therapeutic use of human tissue and cells) was implemented into national law by also extending it to research on human tissue and cells. ${ }^{9}$ Belgium also enacted an opt-out system for human tissue in the case of deceased donors, also applying the rules of the organ donation law of 1986 to this field of regulation. According to the legal provisions, human tissue becomes a 'good' after separation from the human body, which can then be owned by the research institution-for example, a biobank. The Belgian way of dealing with the problem of the value of tissue and body material is also unique, because the royal decree of 14 October 2009 fixes prices for specified human material. ${ }^{4}$ For example, the officially authorised price for a patella is $€ 311$, while a tibia $(>25 \mathrm{~cm}$ ) costs $€ 1.552$, and a heart valve is reflected in the budget at $€ 3.547 .{ }^{4}$ The Belgian lawyer, Herman Nys, humorously commented at the Tiss.EU project workshop in Leiden/Netherlands in December 2009 that this situation demonstrates that Belgium is in reality a socialist country. However, the authors of the above cited study are concerned that the pursuit of economic gain may finally ignore public interest and even compromise the safety of clinical products. As a remedy, the authors suggest allowing only for 'reasonable profit', which should be invested into the improvement of quality, safety and availability of human tissues. $^{10}$

\section{Germany: considerable space for the commercialisation of body material}

In Germany, body material becomes a possessable object after its separation from the human body. This object is then automatically owned by the person from whom it stems. For conducting

iiifor the current status of this Convention's ratification, see http://conventions.coe. int/Treaty/Commun/ChercheSig.asp?NT $=164 \& C M=\& D F=\& C L=E N G$ (accessed 22 December 2010). research with body material, it is necessary that the initial owner transfers the property in the body material to the research institution - an act that is normally performed as part of the informed consent procedure. Neither German law nor other normative guidelines recognise a general ban on the commercialisation of body material. For example, the German Transplantation Law (Transplantationsgesetz, TPG) prohibits in $\S 17$ 'to carry on commerce with organs' (translation by the authors) for therapeutic purposes, but includes no general prohibition of the commercialisation of human body parts. Similarly, the German Transfusion Law formulates in $\S 10$ that the 'Taking of the donation shall take place gratuitously' (translation and emphasis by the authors). However, taken literally, such wording does not forbid financial reward for the blood donor and can rather be seen as a normative ideal for the process of blood donation. ${ }^{3} 11$

\section{Spain: hidden commercial incentives for the donation of body material?}

Although Spanish law perceives the human body as a res extra commercium, donors can retain certain property rights in their samples. While some of these rights are connected to the protection of the donor's personality, others have a rather economic dimension. ${ }^{12}$ In particular, according to the Law on Assisted Human Reproduction Techniques, No. 14/2006 (27 May 2006), the commercial donation of gametes is allowed for assisted reproduction and research. However, this remuneration should only be understood as compensation for the discomforts connected to egg donation. ${ }^{\text {iv }}$ According to the Spanish National Commission on Assisted Reproduction, donors should receive between $€ 600$ and $€ 1000$ for one egg donation cycle. ${ }^{13}$ Furthermore, the law requires that 'Donation must never be promoted by compensation offers or economic benefit' (Art 5 (3)). These provisions obviously stress the donation paradigm in the context of reproduction and research. However, in light of the fact that egg donation often occurs for economic reasons, this paradigm cannot be applied without contradictions. Although, in Spain, surplus egg cells are transferred to research without any additional payment to the donors, it cannot be excluded that 'donation' in the context of reproduction is triggered by economic incentives. In practice, this may turn women into 'donating sellers', while researchers can maintain the pretension of working on unpaid material. ${ }^{14}$

\section{UK: special case with regard to property in the human body?}

The UK can maybe count as the European country that did follow the no-property rule in the strictest sense. For example, Harmon cites a number of cases from UK case law to demonstrate that it was hitherto the 'orthodox view' in UK jurisdiction that 'property cannot be held in the human body, whether living or dead'. ${ }^{15}$ However, the recent case of Yearworth v. North Bristol NHS trust, where six men who had to undergo cancer treatment stored sperm for later reproductive purposes, shows a change in this legal conception. In this case, the court affirmed the position 'that the claimants had ownership rights in their sperm and could sue for interference with those rights'. ${ }^{15}$ However, the impact of this judgement on the prevailing 'orthodox view' may be limited given the special context of the

iv The Law's Art 5(3) stipulates that 'the only remuneration provided will be in the form of compensation and no economic incentive can be sought. Compensation accounts for physical burdens, travel costs and loss of earnings that can arise from the donation process.' 
sperm donors' case. ${ }^{v}$ Harmon not only doubts the 'precedential significance' of the Yearworth judgement, ${ }^{15}$ but suspects this argument also of abetting the body's commodification and commercialisation. From a European point of view, one could also interpret the court decision as a rapprochement between the UK's and the Continental understanding of the no-property rule. However, in the end, the question remains whether differences in the theoretical foundations of ethics and law also amount to real practical differences or whether the practical situation (altruistic donation, then processing and commodification of body material) is quite comparable in the UK and Continental Europe.

\section{CONCLUSIONS}

Recent experience in the area of tissue and organ research with the organ retention scandal in the UK and Ireland shows a considerable lack of transparency in this area, which causes legitimate complaints from patients or their relatives. At the moment, there is an ethical and legal debate going on about whether institutions for tissue research, such as biobanks, have a duty to inform tissue donors about incidental health findings, at least when those findings have importance for individual therapy. Some biobanks explicitly deny their tissue donors such a right to be informed. The examples and analysis of our article show that exact information about the commercialisation of human tissue and body material is also-at least for the broader public-widely hidden behind a 'veil of ignorance'. For example, it was not known to patients and relatives at the UKE that tumour samples would be transferred to a commercial enterprise. It is unlikely that patients and the relatives of deceased patients perceive it as a matter of course that diagnostic samples taken in the course of treatment are later used for commercial activities.

The question is also whether they should have expected such practices in one of the European countries, where, as expressed in a number of international documents and guidelines, 'the human body and its parts shall not give rise to financial gain'. How can this obvious divergence between the pertinent European Conventions and Recommendations, the moral intuitions of European citizens, and the prevalent practices of using human tissues in medical research be explained? Is there a lack of adequate implementation of European Conventions and Recommendations at the national level? Evidence of this could, for example, be derived from the fact that the European Convention on Human Rights and Biomedicine was not ratified by Germany, as well as a number of other European countries. However, a closer look at the Convention's text shows that besides the 'no financial gain' prescription, there is indeed enough room left for the commercial practice of tissue procurement and transfer.

In our view, the following three requirements arise from the scenario that we have outlined.

\footnotetext{
VIn particular, their claim was treated as an issue of bailment wherefore it was argued that the claimants had never abandoned their right of control over their materials. Moreover, the logic of the Yearwoth ruling suggests that it is the intended purpose of the material that determines whether it can be treated within the framework of property or not. Although Yearworth was a rather 'uninspired and uninspiring advancement of the property paradigm' for pragmatic reasons, against the background of former rulings, it cannot simply be regarded an 'outlier' (Harmon and Laurie, p 482). ${ }^{16}$ According to their analysis, Yearworth rather illustrates a 'slow creep in the property paradigm', which is problematic for several reasons. (We gratefully acknowledge Nils Hoppe and Graeme Laurie for clarifying the significance of Yearworth.) For a more detailed analysis and discussion of this case, see also the contribution of Cordell et al in this issue.
}

\section{More information}

Hidden from the eyes of the public, human tissue and body materials have developed into the most important raw material for the progress of medical research. Access to and analysis of collections gathered from hundreds and thousands of patients and stored in large-scale biobanks can bring the next biomedical breakthroughs. However, the patients as the 'sources' of this raw material are only reluctantly informed about this transformation. Public knowledge about the transfer of human tissue, especially for commercial use, is very limited.

\section{More detailed ethical analysis}

Much of the recent discussions has focused on the question of whether commercialisation of human body material should take place. However, a closer look at the diverse normative levels and phenomena in practice reveals a large grey zone with a number of different practices. As we have tried to show, commercialisation of the human body does not follow a binary logic, but consists of several elements or levels, which should be distinguished and analysed individually.

\section{Clear normative statements}

A situation where high-level documents proclaim euphonious normative principles, whereas the situation in practice often seems quite opposed to these principles, is unsatisfactory. Official documents should effectively address the reality of medicine, and not calm patients and citizens by avoiding problematic issues. Such an approach would make it easier to determine whether the commercialisation of human tissue and body material is indeed acceptable to the majority of European citizens.

Funding Tiss.EU project funded within the 7th Framework Program of the European Union (http://www.tisseu.org).

\section{Competing interests None.}

Provenance and peer review Commissioned; externally peer reviewed.

\section{REFERENCES}

1. Anon. Bürgerschaft fordert Transparenz bei Gewebehandel [Citizenry Calls For Transparency Regarding Human Tissue Trade]: Hamburger Abendblatt, 2010. http:// www.abendblatt.de/hamburg/article1437952/Buergerschaft-fordert-Transparenz-beiGewebehandel.html (accessed 22 Dec 2010)

2. Harmon SH. Yearworth v. North Bristol NHS trust: a property case of uncertain significance? Med Health Care Philos 2010;13:343-50.

3. Lenk C. Ökonomie der Körperteile. Wie weit reicht das Kommerzialisierungsverbot des menschlichen Körpers? [Economy of body parts. How far extends the ban on the human body's commercialisation?]. Berliner Debatte Initial 2010;21:9-18.

4. Pirnay JP, Vanderkelen A, Zizi M, et al. Human cells and tissues: the need for a global ethical framework. Bull World Health Organ 2010;88:871, tab.1.

5. Björkman B, Hansson SO. Bodily rights and property rights. J Med Ethics 2006;32:209-14

6. Recommendation Rec(2006)4 of the Council of Europe's Committee of Ministers to Member States on Research on Biological Materials of Human Origin. https://wcd. coe.int/wcd/ViewDoc.jsp?id=977859.

7. Directive 2004/23/EC of the European Parliament and of the Council of 31 March 2004 on Setting Standards of Quality and Safety for the Donation, Procurement, Testing, Processing, Preservation, Storage and Distribution of Human Tissues and Cells. http://eur-lex.europa.eu/LexUriServ/LexUriServ.do?uri=0J: L:2004:102:0048:0058:en:PDF.

8. Beier K, Lenk C. A unified European approach on tissue research and biobanking? A comparison. In: Lenk C, Sándor J, Gordijn B, eds. Biobanks and Tissue Research the Public, the Patient and the Regulation. Dordrecht: Springer Publishing, 2011. ch.10 (in print).

9. Loi relative à l'obtention et à l'utilisation de matériel corporel humain destiné à des applications médicales humaines ou à des fins de recherch scientifique. [Belgian Law of 19th December 2008 Regulating the Procurement and the Use of Human Bodily Material for Medical Application in Humans or for Scientific Research]. http://suisse. juridat.be/cgi loi/loi F.pl?cn=2008121944.

10. Pirnay JP, Vanderkelen A, Zizi M, et al. Human cells and tissues: the need for a global ethical framework. Bull World Health Organ 2010;88:872. 
11. Taupitz J. Das Verbot der Kommerzialisierung des menschlichen Körpers und seiner Teile: Lässt es sich rational begründen?' [The prohibition of the commercialisation of the human body and its parts: Can it be justified rationally?]. In: Taupitz J, ed. Kommerzialisierung des menschlichen Körpers. [Commercialisation of the human body]. Berlin, Heidelberg: Springer, 2007:4f.

12. Report of the 3rd International Workshop of the Tiss. Paris: EU Project, 2009. http://www. tisseu.uni-hannover.de/images/files/report_paris_final.pdf (accessed 28 Dec 2010).

13. Velasco JG. Egg donation in Spain. The Spanish point of view. Focus on Reproduction (Newsletter of the European Society of Human Reproduction and
Embryology, May 2007) 2007:5:26-30. http://www.eshre.eu/binarydata.aspx? type $=$ doc\&sessionld=sft2fr2rc1wfzm55m32me045/MAY2007_ISSUE.pdf.

14. Schultz S, Braun K. Spendende Verkäuferinnen. Eizellen für die Klonforschung [Donating sellers. Egg cells for cloning research]. Berliner Debatte Initial 2010;21:28-40.

15. Harmon SH. Yearworth v. North Bristol NHS Trust: a property case of uncertain significance? Med Health Care Philos 2010;13:343-50.

16. Harmon SH, Laurie G. Yearworth v. North Bristol NHS Trust: property, principles, precedents and paradigms. Cambridge Law J 2010;69:476-93.

\section{DIFFERENTIAL DIAGNOSIS}

\section{Trustworthy guidance on your iPhone}

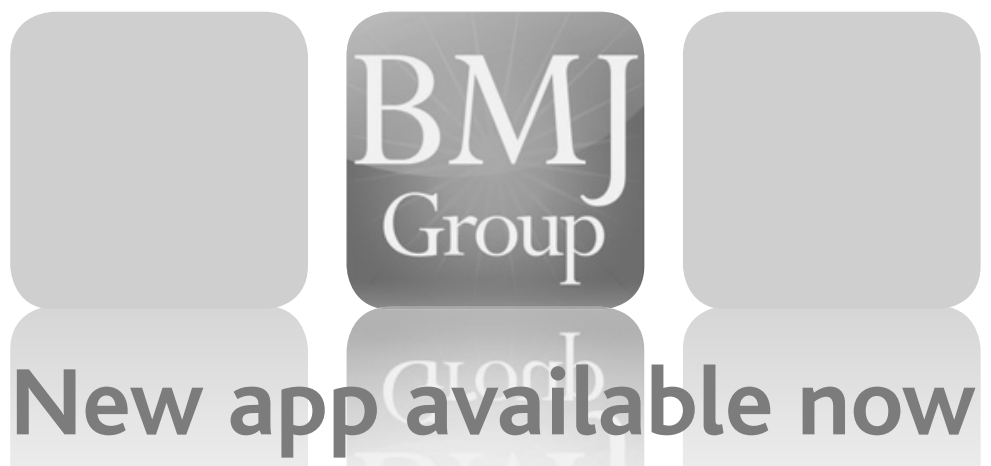

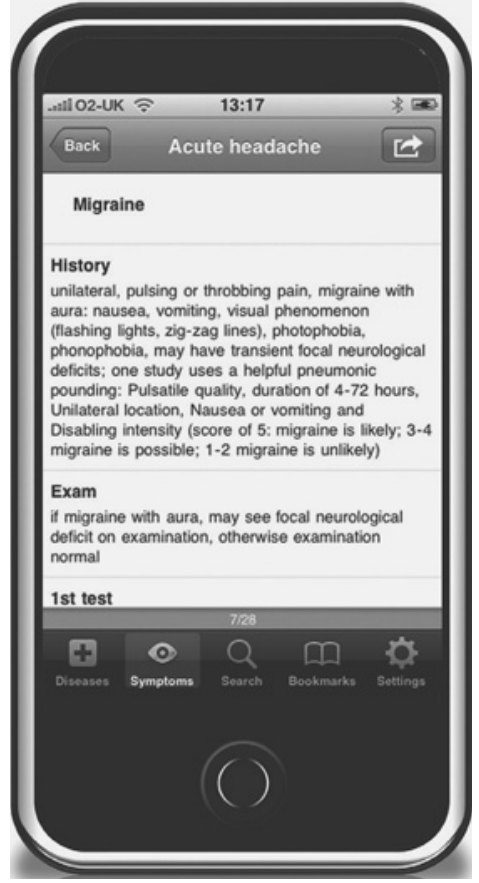

\section{Find out more at bestpractice.bmj.com/differentials}




\section{Is the commercialisation of human tissue and body material forbidden in the countries of the European Union?}

Christian Lenk and Katharina Beier

J Med Ethics 2012 38: 342-346 originally published online June 22, 2011

doi: 10.1136/jme.2010.038760

Updated information and services can be found at:

http://jme.bmj.com/content/38/6/342.full.html

\section{These include:}

References This article cites 9 articles, 1 of which can be accessed free at: http://jme.bmj.com/content/38/6/342.full.htmI\#ref-list-1

Email alerting Receive free email alerts when new articles cite this article. Sign up in service the box at the top right corner of the online article.

\begin{tabular}{cc}
$\begin{array}{c}\text { Topic } \\
\text { Collections }\end{array}$ & $\begin{array}{c}\text { Articles on similar topics can be found in the following collections } \\
\text { Informed consent (221 articles) } \\
\text { Legal and forensic medicine (336 articles) }\end{array}$ \\
\hline
\end{tabular}

Notes

To request permissions go to:

http://group.bmj.com/group/rights-licensing/permissions

To order reprints go to:

http://journals.bmj.com/cgi/reprintform

To subscribe to BMJ go to:

http://group.bmj.com/subscribe/ 